\title{
Quantitative immunohistochemical analysis of duodenal ghrelin cells after sleeve gastrectomy in Wistar rats ${ }^{1}$
}

\author{
Análise imunoistoquímica quantitativa das células de grelina duodenais após gastrectomia \\ vertical em ratos Wistar
}

\begin{abstract}
Marcelo Bianchini Teive', Ricardo Fantazzinni Russi' ${ }^{\mathrm{II}}$, Daniella Serafim Couto Vieira ${ }^{\mathrm{III}}$, André Muller Teive ${ }^{\mathrm{IV}}$, Aline Costa ${ }^{\mathrm{V}}$, Armando Jose d'Acampora ${ }^{\text {VI }}$

${ }^{\mathrm{I} M a s t e r}$, Associate Professor, Department of Surgery, University Hospital, UFSC, Florianopolis-SC, Brazil. Conception and design, acquisition of data, manuscript writing.

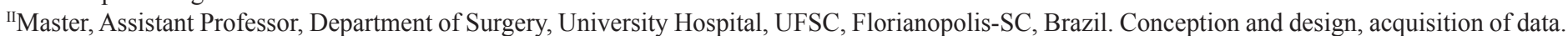

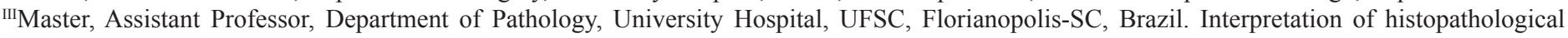
results.

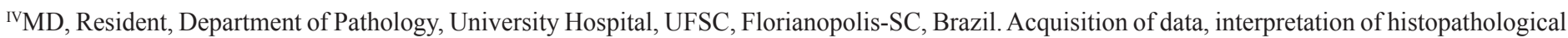
results.

${ }^{v}$ Master, Department of Pathology, University Hospital, UFSC, Florianopolis-SC, Brazil. Acquisition of data, interpretation of laboratory data. ${ }^{\mathrm{V}} \mathrm{PhD}$, Associate Professor, Department of Surgery, University Hospital, UFSC, Florianopolis-SC, Brazil. Conception and design, final approval.
\end{abstract}

\begin{abstract}
PURPOSE: Sleeve gastrectomy (SG) removes substantial part of the gastric mucosa, which produces ghrelin. This reduction is expected to force other organs, such as the duodenum, to compensate by increasing the number of ghrelin-producing cells. The purpose of this study was to evaluate whether this response occurs.

METHODS: Twelve adult male, Wistar rats underwent SG and were reoperated 30 or 60 days after the initial surgery. During the second surgery, a segment of the duodenum was resected to count ghrelin cells using immunohistochemistry. In six animals, SG was not performed, and the duodenal segment served as a control for ghrelin cell counts. The ghrelin cell index (GCI), which is the number of ghrelin cells divided by the number of villi in each segment, was measured and used in statistical analysis by one-way analysis of variance (ANOVA).
\end{abstract}

RESULTS: There were increases in the absolute numbers of cells 30 and 60 days after SG, but statistical analysis by ANOVA showed no significant difference between the groups.

CONCLUSION: A compensatory increase in the number of duodenal immunopositive ghrelin cells did not occur as a response to sleeve gastrectomy.

Key words: Ghrelin. Gastrectomy. Bariatric Surgery. Rats, Wistar.

\section{RESUMO}

OBJETIVO: A gastrectomia vertical $(\mathrm{GV})$ remove a maior parte das células produtoras de grelina. Esta redução poderia induzir o duodeno a produzir mais células de grelina de forma compensadora. O objetivo deste trabalho foi estudar se esta compensação ocorre. MÉTODOS: Doze ratos Wistar, machos, foram submetidos à GV e reoperados 30 e 60 dias depois (grupos 30D e 60D) quando um segmento de duodeno foi ressecado para contagem de células de grelina por imunoistoquímica. Em seis animais não foi realizada a GV e um segmento de duodeno foi ressecado para contagem de células de grelina por imunoistoquímica (grupo controle). O índice de células de grelina (ICG), que é o número de células imunopositivas para grelina dividido pelo número de vilosidades do segmento foi calculado e utilizado na análise estatística pelo teste da análise de variância (ANOVA).

RESULTADOS: Houve aumento no número absoluto de células 30 e 60 dias depois da gastrectomia vertical, mas a análise estatística por ANOVA não mostrou diferenças significantes entre os grupos.

CONCLUSÃO: Não foi observado aumento compensatório no número de células de grelina duodenais após a gastroplastia vertical.

Descritores: Grelina. Gastrectomia. Cirurgia Bariátrica. Ratos Wistar. 


\section{Introduction}

Ghrelin is a peptide produced mainly by the X/A-like cells of the gastric fundus. It exhibits strong growth hormone (GH)-releasing activity and this effect is mediated by activation of the GH secretagogue receptor type 1a (GHS-R 1a). This receptor is specific for a family of synthetic peptidyl and nonpeptidyl growth hormone secretagogues (GHS) ${ }^{1}$.

Ghrelin has other functions in the body such as influencing the pituitary gonadal axis, appetite stimulation, control of energy balance, influence of sleep and behavior, control of gastric motility and acid secretion, and influencing both pancreatic exocrine and endocrine functions and glucose metabolism. The actions on the cardiovascular system, some effects on the proliferation of neoplastic cells, and the effects on the immune system were also described ${ }^{1}$. Ghrelin is considered to be a gastrointestinal peptide that contributes to the regulation of many functions of the gutbrain axis. There is a strong possibility that ghrelin analogs acting as either agonists or antagonists might be clinically useful ${ }^{1}$.

Ghrelin was identified in 1999 in Japan as an endogenous ligand for the former orphan receptor GHS-R 1a. The discovery of this receptor occurred 20 years after the discovery of the specificbinding and synthetic GHS ${ }^{1,2}$.

The discovery of ghrelin is an important example of reverse pharmacology, which in this particular case, began with the synthesis of analogs and ended with the discovery of the natural ligand through the discovery of a natural receptor ${ }^{1,2}$.

The hydroxyl group of ghrelin has a serine residue (serine 3 ) that is acylated by n-octanoic acid. This acylation is essential for its binding to GHS-R 1a and for the GH-releasing ability of ghrelin. This acylation is also important for its other endocrine actions. Nonacylated ghrelin is present in human serum in greater quantities than acylated ghrelin. It is thought to have no endocrine function, but it is capable of exerting some nonendocrine actions such as cardiovascular and antiproliferative effects, which are most likely mediated by its binding to different GHS-R subtypes ${ }^{1,3}$

Another type of ghrelin, which is an endogenous ligand for GHS-R 1a, can be isolated from the endocrine mucosa of the stomach. This type is known as Des-Gln14 ghrelin and exhibits the same serine acylation but lacks one glutamine. This subtype is the result of alternative gene splicing and appears to have hormonal activities identical to the original ghrelin ${ }^{1,4}$.

Ghrelin can be found in areas from the stomach to the colon with a decreasing number of cells in caudal regions, which confirms that X/A-like cells (producers of gastric ghrelin) are not present only in the oxyntic mucosa. Most of the enteroendocrine cells containing ghrelin exhibit no continuity with the gastrointestinal lumen, and these cells are known as closed-type cells. Another type of cell that has physical contact with the lumen is known as the opened-type cell. The frequency of this latter type of cell increases caudally, but the overall number is much greater than the opened-type counterpart found in the upper segments of the gastrointestinal tract ${ }^{5}$.

The plasma levels of ghrelin in gastrectomized patients are reduced to approximately half of the preoperative values and gradually increase. This fact strongly suggests that the stomach is the main source of ghrelin and that other tissues compensate for this loss after total gastrectomy ${ }^{6,7}$.

In humans, ghrelin immune-reactive cells are most numerous in the stomach oxyntic mucosa and are less frequent in the duodenum, occasionally in the jejunum, rare in the ileum and undetectable in the colon. Most of these cells were found in the crypts of Lieberkühn ${ }^{8}$.

SG has recently gained popularity among bariatric surgeons. It is a purely restrictive operation that was initially performed in high body mass index (BMI) patients but is now being proposed as the sole appropriate weight-loss operation for lower-BMI individuals. Comorbidities such as hypertension, hyperlipidemia, diabetes and sleep apnea exhibited resolution rates comparable to other restrictive procedures. SG exhibits advantages when compared to other bariatric surgery techniques. There is no insertion of a foreign body (band), and the pylorus and the antral mill are preserved, which prevents dumping syndrome. The hospitalization required after this procedure is shortened with the laparoscopic approach, and the patient can take oral medications and eventually undergo endoscopy ${ }^{9}$.

Some investigators have observed a late serum ghrelin increase after many types of bariatric procedures including $\mathrm{SG}$, but these results are still controversial ${ }^{10}$.

The purpose of this work was to analyze the possibility of an increase in the number of duodenal ghrelin cells as a compensatory response induced by the large removal of these cells by SG.

\section{Methods}

The Federal University of Santa Catarina Committee of Ethics in the Use of Animals (CEUA) approved all the animal experimental procedures (protocol \# PP 0252).

Eighteen adult male Wistar rats weighing 250-350g were used in this experiment. The animals were randomly allocated into 
three groups of six rats each: controls (C), 30 days (30D) and 60 days (60D). All the animals were housed in individual plastic cages and were allowed to eat standard rat chow and tap (chlorinated) water ad libitum.

\section{Surgical procedures}

Rats were anesthetized with an intramuscular injection of $100 \mathrm{mg} / \mathrm{kg}$ of ketamine and $10 \mathrm{mg} / \mathrm{kg}$ xylazine.

Group C animals were submitted to a midline laparotomy to remove the first $5 \mathrm{~cm}$ of the duodenum. The specimens were preserved in a buffered formaldehyde solution. The rats were euthanized by an intracardiac potassium chloride injection.

The 30D and 60D groups were submitted to a modification of a previously described technique of $\mathrm{SG}^{11}$. The modifications that were introduced consisted of a second row of reinforcing sero-serosal running sutures with 6-0 Prolene ${ }^{\circledR}$ (Ethicon, SP, Brazil) and no emptying of the remaining gastric food to the intestine to avoid trauma to the duodenal mucosa. Ten milliliters of saline was subcutaneously injected in the final step of every procedure for hydration. In the first two postoperative days, rats were fed a liquid diet composed of $5 \%$ glucose $+0.9 \%$ saline solution + Glicopan pet ${ }^{\circledR}$ (Vetnil, SP, Brazil) a solution containing vitamins and amino acids used for nutritional supplementation of small animals. On postoperative day 3 , animals resumed regular rat chow and water ad libitum. They were reoperated 30 or 60 days after the $\mathrm{SG}$. The first $5 \mathrm{~cm}$ of the duodenum was removed, and the animals were euthanized as described for group C. All the procedures were performed under sterile conditions. The resected duodenum samples were immediately placed in a buffered $10 \%$ formalin solution.

\section{Histopathological procedures}

A middle longitudinal strip of the $5-\mathrm{cm}$ duodenal segments, $2 \mathrm{~mm}$ wide (pancreatic side) was cut and divided into three sections (proximal, middle and distal) to fit on a single microscopic slide. The specimens were processed, and paraffin blocks were prepared to make slides for both hematoxylin-eosin and immunohistochemical staining.

\section{Immunohistochemistry}

Tissues were stained immunohistochemically using the labeled streptavidin biotin method (LSAB). Briefly, the specimens were deparaffinized, rehydrated and incubated with
$0.3 \%$ hydrogen peroxide in methanol for 20 minutes to block endogenous peroxidase activity. Antigen retrieval was performed using citrate buffer ( $\mathrm{pH} \mathrm{6.0)}$ for 40 minutes at $95-98^{\circ} \mathrm{C}$, and the specimens were left to cool for 30 minutes at room temperature. The specimens were incubated with primary rabbit anti-ghrelin (rat-mouse) antibody (Phoenix Pharmaceuticals, CA, USA) diluted $1: 10.000$ for 12 hours at $8^{\circ} \mathrm{C}$ in a humidified chamber and with the biotinylated secondary antibody (Dako, CA, USA) for 30 minutes at room temperature. The specimens were incubated with streptavidin conjugated to peroxidase (Dako, CA, USA) for 40 minutes at room temperature and were treated for 1 minute with 3-3-diaminobenzidine (DAB), which acted as a chromogen. The specimens were counterstained with Harris hematoxylin for 9 minutes, dehydrated in a graded ethanol series, clarified with xylene and mounted under coverslips with ERV-MOUN (EasyPath, SP, Brazil). The rat stomach, which is known to express ghrelin, was used as a positive control for the experiment, and the negative control was a specimen that received phosphate buffer solution (PBS) instead of primary antibody. The positive result was indicated by the appearance of brown color in the antibodybinding site.

Cell counting, statistical analysis and Ghrelin Cell Index $(G C I)$

Each microscopic slide contained three portions of the 5-cm duodenal segment: proximal, middle and distal. A pathologist blinded to the experimental conditions used a light microscope to count all the immunopositive ghrelin cells and all the villi. Three full countings were performed, and the last counting results were used in the analysis. Only the nucleated cells with brown chromogen in the cytoplasm or in any part of the cell membrane were considered for counting. The opened- and closedtype cells were counted. The GCI was defined as the number of ghrelin cells divided by the number of corresponding villi in each slide. One-way ANOVA was used to assess statistical significance, which was set at $p<0.05$. Data are presented as the means and SD. SSPS statistics software (SSPS, Inc., IL, USA) was used for data processing.

\section{Results}

All the animals had solid food in their stomachs at the time of the reoperations.

Ghrelin immunopositive cells were only observed in the villi and crypts of the mucosal layer. Figures 1 and 2 show immunopositive duodenal ghrelin cells staining in villi and crypts. 


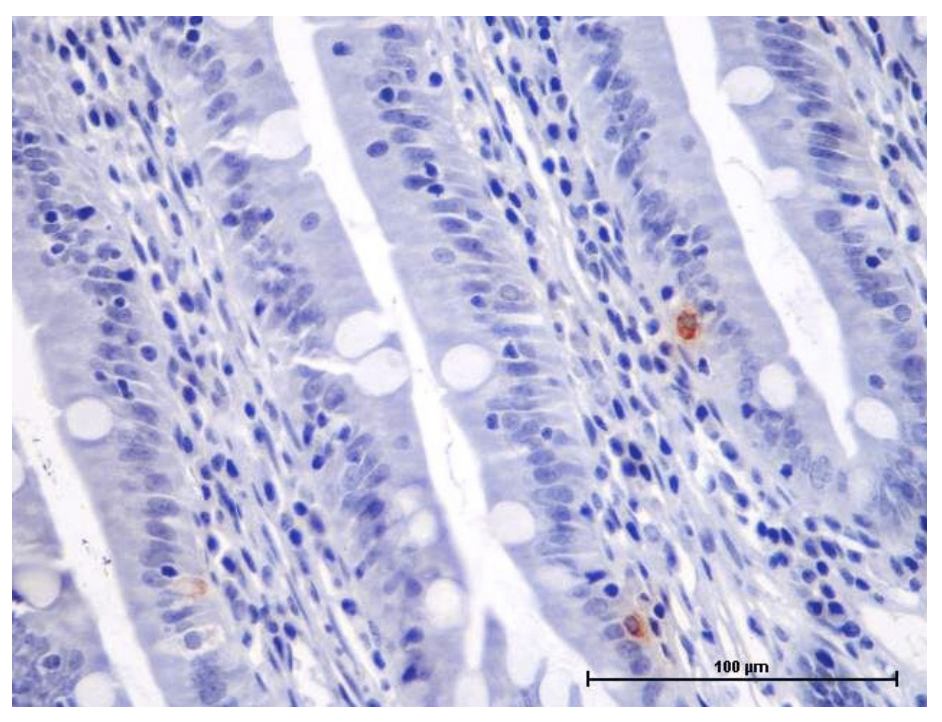

FIGURE 1 - Ghrelin immunopositive cells in duodenal villi (400x).

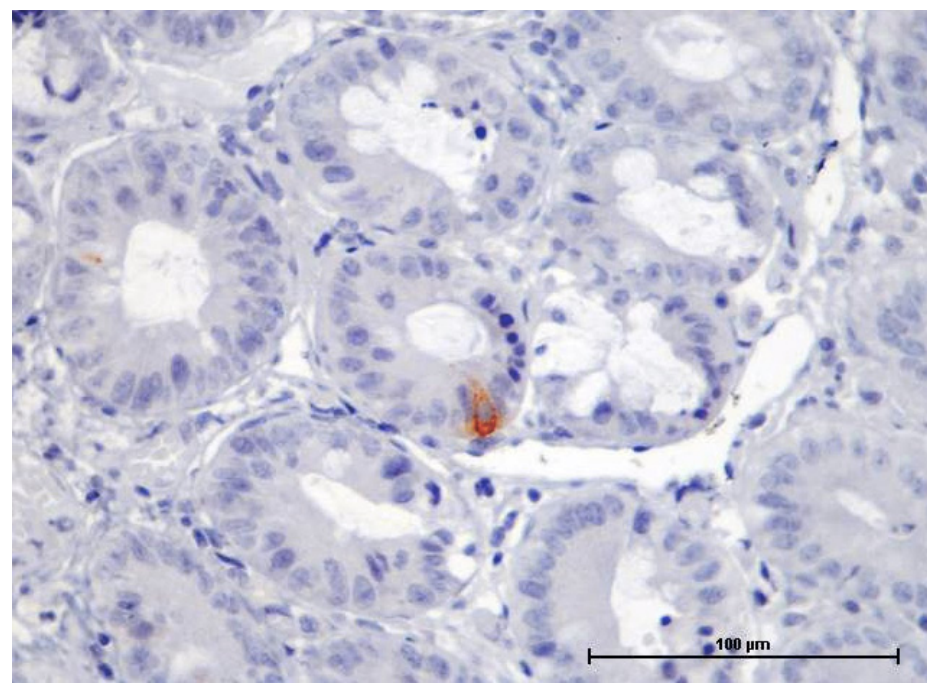

FIGURE 2 - Immunopositive open-type ghrelin duodenal cell in crypt (400x).

Table 1 shows the results for each group including the number of immunopositive ghrelin cells, the opened-type cell number, the villi number and the GCI. The number of opened-type cell was included in the totals for each group.

TABLE 1 - Number of cells, villi and GCI ${ }^{\mathrm{a}}$ in each group.

\begin{tabular}{cccc}
\hline Group & Ghrelin cells & Number of villi & GCI \\
\hline C & $263(4)^{\mathrm{b}}$ & 1557 & 0.16 \\
30D & $280(4)^{\mathrm{b}}$ & 1481 & 0.18 \\
60D & $351(8)^{\mathrm{b}}$ & 1576 & 0.22 \\
\hline
\end{tabular}

${ }^{a}$ GCI: ghrelin cell index

${ }^{\mathrm{b}}$ Number of opened-type cells in parentheses

An ANOVA test was used to analyze the possible differences among the groups, mainly between the control group and 30D and 60D groups (Table 2).

TABLE 2 - Comparisons of $\mathrm{GCI}^{\mathrm{a}}$ between groups.

\begin{tabular}{ccc}
\hline Groups & Mean & Standard deviation \\
\hline C & 0.282 & 0.823 \\
30D & 0.343 & 0.798 \\
60D & 0.338 & 0.134 \\
& & $\mathrm{P}=0.53 *$ \\
\hline
\end{tabular}

${ }^{a} \mathrm{GCI}$ : ghrelin cell index

* One-way ANOVA $(95 \% \mathrm{CI})$

Statistical analysis showed no significant compensatory increase in the number of ghrelin immunopositive cells in a duodenum sample of rats submitted to SG 30 and 60 days after the operation.

\section{Discussion}

We investigated the hypothesis that the rat duodenum could increase the number of ghrelin cells to compensate for the lack of gastric tissue containing ghrelin-producing cells after its removal by $\mathrm{SG}$.

Human plasma levels of immunoreactive ghrelin are reduced to approximately half of the pre-gastrectomy values and gradually increase, which suggests that other tissues compensate for the loss of ghrelin production after gastrectomy ${ }^{6}$.

Reduced plasma levels of ghrelin in humans in the early postoperative period were observed. However, a compensatory increase in the plasma ghrelin levels, most likely due to production of ghrelin by other tissues, may limit the success of SG in the longer follow-up. It was reported that among tissues, the duodenum has the second greatest number of ghrelin cells ${ }^{12,13}$.

It is well known that stem cells in intestinal crypts proliferate and generate cells that migrate upwards and differentiate into endocrine cells such as ghrelin cells and other cells, including goblet and absorptive cells ${ }^{14}$.

Based on these concepts and on the similarity of ghrelin cells in rats and humans, we conceived that duodenal stem cells could give rise to new ghrelin cells in response to a negative feedback originating from the partial lack of its main production site caused by SG. The number of ghrelin immunopositive cells in the duodenum is much lower than the number in the stomach, as reported by Sakata and Sakai ${ }^{15}$. The gastric fundus contains 10-20 times more ghrelin per $1 \mathrm{~g}$ of tissue than the duodenum, which is the next richest source ${ }^{13}$. 
We analyzed the first $5 \mathrm{~cm}$ of the duodenum in two groups of six Wistar rats at 30 and 60 days after SG, and because of the paucity of ghrelin duodenal cells, we counted all the cells in all the sections.

The macroscopic duodenum segment resulted in sections that did not contain the same number of villi in each animal. To correct this bias, we normalized the number of ghrelin cells to the number of villi in each section and referred to this number as the GCI.

The GCI was obtained by dividing the number of immunopositive ghrelin cells by the number of villi in the three sections for each rat to avoid bias due to the slightly different sizes of the sections.

The amount of ghrelin inside the ghrelin-producing cells in fast and fed states remains controversial. In our work, rats were not fasted preoperatively in an attempt to keep their stomachs filled with food and thus maintain the highest possible amount of ghrelin inside the cells ${ }^{15,16}$.

\section{Conclusion}

A compensatory increase in the number of duodenal immunopositive ghrelin cells did not occur as a response to sleeve gastrectomy.

\section{References}

1. van der Lely AJ, Tschop M, Heiman ML, Ghigo E. Biological, physiological, pathophysiological, and pharmacological aspects of ghrelin. Endocr Rev. [Review]. 2004;25(3):426-57.

2. Masayasu Kojima HH, Yukari Date, Masamitsu Nakazato, Hisayuki Matsuo Kenji Kangawa. Ghrelin is a growth-hormone- releasing acylated peptide from stomach. Nature. 1999;402:656-60.

3. Date Y, Kojima M, Hosoda H, Sawaguchi A, Mondal MS, Suganuma T, Matsukura S, Kangawa K, Nakazato M. Ghrelin, a novel growth hormone-releasing acylated peptide, is synthesized in a distinct endocrine cell type in the gastrointestinal tracts of rats and humans. Endocrinology. 2000;141(11):4255-61.

4. Hosoda H, Kojima M, Matsuo H, Kangawa K. Ghrelin and des-acyl ghrelin: two major forms of rat ghrelin peptide in gastrointestinal tissue. Biochem Biophys Res Commun. 2000;279(3):909-13.

5. Sakata I, Nakamura K, Yamazaki M, Matsubara M, Hayashi Y, Kangawa K, Sakai T. Ghrelin-producing cells exist as two types of cells, closed- and opened-type cells, in the rat gastrointestinal tract. Peptides. 2002;23(3):531-6.

6. Hosoda H, Kojima M, Mizushima T, Shimizu S, Kangawa K. Structural divergence of human ghrelin. Identification of multiple ghrelin-derived molecules produced by post-translational processing. J Biol Chem. 2003;278(1):64-70.

7. Moller N, Nygren J, Hansen TK, H OR, Frystyk J, Nair KS Splanchnic release of ghrelin in humans. J Clin Endocrinol Metab. 2003;88(2):850-2.

8. Gronberg M, Tsolakis AV, Magnusson L, Janson ET, Saras
J. Distribution of obestatin and ghrelin in human tissues: immunoreactive cells in the gastrointestinal tract, pancreas, and mammary glands. J Histochem Cytochem. 2008;56(9):793-801.

9. Papailiou J, Albanopoulos K, Toutouzas KG, Tsigris C, Nikiteas N, Zografos G. Morbid obesity and sleeve gastrectomy: how does it work? Obes Surg. 2010;20(10):1448-55.

10. Tymitz K, Engel A, McDonough S, Hendy MP, Kerlakian G. Changes in ghrelin levels following bariatric surgery: review of the literature. Obes Surg. 2011;21(1):125-30.

11. de Bona Castelan J, Bettiol J, d'Acampora AJ, Castelan JV, de Souza JC, Bressiani V, Giroldi SB. Sleeve gastrectomy model in Wistar rats. Obes Surg. 2007;17(7):957-61.

12. Bohdjalian A, Langer FB, Shakeri-Leidenmuhler S, Gfrerer L, Ludvik B, Zacherl J, Prager G. Sleeve gastrectomy as sole and definitive bariatric procedure: 5-year results for weight loss and ghrelin. Obes Surg. 2010;20(5):535-40.

13. Zhao Z, Sakai T. Characteristic features of ghrelin cells in the gastrointestinal tract and the regulation of stomach ghrelin expression and production. World J Gastroenterol. 2008;14(41):6306-11

14. Schauser K, Larsson LI. Programmed cell death and cell extrusion in rat duodenum: a study of expression and activation of caspase-3 in relation to $\mathrm{C}$-jun phosphorylation, DNA fragmentation and apoptotic morphology. Histochem Cell Biol. 2005;124(3-4):237-43.

15. Sakata I, Sakai T. Ghrelin cells in the gastrointestinal tract. Int J Pept. 2010;2010.

16. Sonmez MF, Ozan E. Determination of ghrelin immunoreactivity in the rat stomach after fasting and refeeding. Acta Histochem. 2007;109(3):193-9.

\section{Correspondence:}

Marcelo Bianchini Teive

Rua Almirante Lamego, 747/706

88015-600 Florianópolis - SC Brasil

Tel.: (55-48)3225-3274

Fax: (55-48)3721-8045

teivemb@matrix.com.br

Received: April 16, 2012

Review: June 14, 2012

Accepted: July 17, 2012

Conflict of interest: none

Financial source: none

${ }^{1}$ Research performed at Laboratory of Technique and Experimental Surgery, Department of Surgery and Laboratory of Pathology, University Hospital, Federal University of Santa Catarina (UFSC), Florianopolis, Brazil. 